\title{
Article
}

\section{An Observational Narrative of Student Reaction to Video Hooks}

\author{
Veronica McCauley $^{1, *(D)}$ and Martin McHugh ${ }^{2}$ (D) \\ 1 School of Education, National University of Ireland, H91 TK33 Galway, Ireland \\ 2 SSPC, the SFI Research Centre for Pharmaceuticals, Bernal Institute, University of Limerick, \\ V94 T9PX Limerick, Ireland; martin.mchugh@ul.ie \\ * Correspondence: veronica.mccauley@nuigalway.ie
}

\section{check for}

updates

Citation: McCauley, V.; McHugh, M. An Observational Narrative of Student Reaction to Video Hooks. Educ. Sci. 2021, 11, 286. https:// doi.org/10.3390/educsci11060286

Academic Editor: Eleanor Dommett

Received: 13 May 2021

Accepted: 1 June 2021

Published: 8 June 2021

Publisher's Note: MDPI stays neutral with regard to jurisdictional claims in published maps and institutional affiliations.

Copyright: (c) 2021 by the authors. Licensee MDPI, Basel, Switzerland. This article is an open access article distributed under the terms and conditions of the Creative Commons Attribution (CC BY) license (https:// creativecommons.org/licenses/by/ $4.0 /)$.

\begin{abstract}
Digital video has become a dominant form of student learning in and beyond the classroom, and thus its pervasive nature in contemporary learning environments commands scholarly inquiry. In this paper we explore a participatory design-based research approach to the integration of video hook technology in the post-primary science classroom (students aged 12-15). Video hooks were designed with the intention of engaging students and augmenting their interest in science. Teachers across ten schools voluntarily agreed to implement the video hooks, and with their students $(N=128)$ engage in a qualitative, observational methodology to ascertain their effect. Triangulated data was collected through teacher interviews $(N=10)$, structured lesson observation and researcher journal documentation. Results reveal that student reaction was instant and impactful with evidence of both triggered and maintained student interest.
\end{abstract}

Keywords: video hooks; engagement; interest; science teaching; observation

\section{Introduction}

The quality and content of instruction [1,2], along with educational technologies grounded in practical pedagogy $[3,4]$ are denoted as large determinants of student interest and engagement in learning. Furthermore, classroom learning that is enhanced by technology is continually garnering momentum as governments strive for knowledge economies driven by a population that is tech-literate [5]. Given this, educational technology is positioned at the vanguard of modern instruction and innovation, and the opportunity to examine educational technologies and appropriate pedagogical methodologies is warranted [6], in this instance, those that augment interest and engagement. Video hooks provide one such opportunity. Based on the limited literature, a hook is defined as a short instructional method utilized at the beginning of instruction to augment interest, engagement and attention among the student body [7-9]. Hooks, their design, use in video format and/or associated reactive methodologies represent an area of instruction that has been traditionally understudied in educational literature [10], yet they are central aspects of instructional frameworks and colloquially present in teachers' toolkits. This paper reports on the integration of a set of novel video-based hooks in the science classroom. The video hooks (see reference 76 for design details) were designed with the intention of engaging students and heightening their interest in science.

A participatory design approach [11-15] was employed, and post-primary/middle school teachers across ten schools voluntarily agreed to implement the video hooks with their students $(N=128)$, and engage in a qualitative, observational methodology to ascertain their effect. Representative data was utilized to illustrate the effect of the video hooks on the classroom ecology from a teacher and researcher/observer perspective. The overarching research question asks: What are the observed reactions of students (in terms of attention, interest and engagement) when video hooks are embedded in their physics lesson. 


\section{Video Hooks and Conceptual Framework}

\subsection{Setting the Context}

Learning enhanced by technology has gathered momentous energy in recent years, heightened further with the colossal impact of COVID-19 on our education system [16,17], with educators engaging in 'crisis learning' in imposed virtual environments [18]. Cognisant of the abrupt transition to online learning, it is important to note that educational technologies in particular multimedia are viewed as a way of improving instruction [19].

The models and roles of multimedia in science education have gained theoretical and practical attention from the high volume of readily available technology present in society that is permeating into classrooms [20,21]. Today's students are 'digital natives' who have not known life without the Internet-so much so, that some research claims that "Generation Zers' brains are structurally different to those of previous generations: surrounded by complex visual imagery, the part of their brain responsible for visual ability is more developed, making them more reactive to "visual learning" [18] (p. 2). Thus the visual medium of digital video, as a choice of hook method, was a natural fit for this cohort of school students.

\subsection{Video Hook Design}

The physics video hooks include a series of nine instructional resources for physics classrooms (https: / / sciencehooks.scoilnet.ie/physics/, accessed on 3 June 2021) with postprimary level students (age 12-15; middle school). Table 1 describes the hooks used in this study.

Table 1. List of hook videos with description and duration.

\begin{tabular}{|c|c|c|}
\hline Hook Video & Description & Duration \\
\hline Atmospheric Pressure & $\begin{array}{l}\text { This hook displays how atmospheric pressure can be used to crush aluminium } \\
\text { cans. A can is filled with steam and then inverted into cold water. The steam } \\
\text { condenses to create a vacuum and the pressure of the atmosphere forces the can } \\
\text { to implode. }\end{array}$ & $1: 36$ \\
\hline Centre of Gravity & $\begin{array}{l}\text { This hook takes objects that do not intuitively balance and puts them together. } \\
\text { Three separate balancing acts are presented; the combination of a spoon, fork } \\
\text { and toothpick, a hammer ruler and string and finally a sledgehammer, twine } \\
\text { and a metre stick. }\end{array}$ & $1: 45$ \\
\hline Conservation of Energy & $\begin{array}{l}\text { This hook displays the concept of the conservation of energy, the principle that } \\
\text { energy cannot be created or destroyed; it can only be changed from one form to } \\
\text { another. In the experiment, a weight is tied onto a piece of string and used as a } \\
\text { pendulum. }\end{array}$ & 1:08 \\
\hline Density & $\begin{array}{l}\text { This hook displays a density tower. Various immiscible (will not mix) liquids are } \\
\text { placed in a graduated cylinder to see which ones are the most and least dense. }\end{array}$ & $2: 57$ \\
\hline Energy Conversions & $\begin{array}{l}\text { This hook turns chemical energy into heat energy and then into kinetic energy } \\
\text { by using water as an energy transporter and converter in a simple steam engine. }\end{array}$ & $1: 34$ \\
\hline Flotation & $\begin{array}{l}\text { This hook explores the density of objects in relation to water. Objects include } \\
\text { fruit, soda cans and eggs. }\end{array}$ & $1: 28$ \\
\hline Friction & $\begin{array}{l}\text { This hook examines friction as a force and lubrication. It demonstrates the } \\
\text { frictional force by inserting a knife into a graduated cylinder of rice. }\end{array}$ & $1: 11$ \\
\hline Pressure & $\begin{array}{l}\text { This hook explores pressure and area by placing a balloon on a single nail versus } \\
\text { a bed of nails. }\end{array}$ & $0: 42$ \\
\hline Sound & $\begin{array}{l}\text { In this hook, the sound made by a tuning fork is explored. If the tuning fork is } \\
\text { struck, the vibrations created in the air produce a quiet sound and force. The } \\
\text { force is then used to create a piece of art. }\end{array}$ & $1: 29$ \\
\hline
\end{tabular}

The video hooks were created as part of a collaborative design project with teacher educators and student physics teachers using a modified Analysis, Design, Development, 
Implementation and Evaluation (ADDIE) design framework, as it allowed videos to be developed in a practical and efficient manner [9]. All the videos cover different scientific topics and phenomena; however, all topics were distilled and presented under the same initial design considerations so that the intended impact from all videos is the same. Firstly, the design takes into account cognitive theories of multimedia learning, in that the resources are streamlined to be impactful and easily understood by a first-time viewer $[22,23]$. Secondly, every video is embedded with the same design elements. These include relevance (to curriculum and everyday life) [24], questioning (displayed on screen or combined with narration) [25] and discrepancy (phenomena, that visually does not make sense based on viewers level of knowledge or misconceptions) [26]. The pedagogical framework consisted of three pillars: to affect interest, engagement and attention among learners, and their intended use was to provide a grounding for the instruction that followed.

\subsection{Conceptual Framework: Interest, Attention, Engagement}

Emergent hook theory emanates from three broad areas of inquiry: (1) interest $[27,28]$, (2) attention $[7,29,30]$ and (3) engagement $[31,32]$. The constructs are explored briefly here in line with their theoretical convergence.

\subsubsection{Interest}

Interest, as an active state, brings individuals into contact with new knowledge and experiences that go beyond their current boundary of information and achievement (48). Characteristically, the patterns of interest represented by an individual predict future preferences and motivations of action [33] rendering it a vital trait in educational environs [34-37]. Situational interest is defined by Schraw et al. [38] (p. 211) as 'temporary interest that arises spontaneously due to environmental factors such as task instruction or an engaging text'. It is the type of interest a student develops in a subject due to their surrounding environment and teacher, and it is pivotal in educational settings as it aids in both learning and memory function [39].

Similar to interest as a whole, situational interest can be further broken down into triggered situational interest and maintained situational interest, often referred to as the 'catch' and 'hold' of interest, respectively [40,41]. The triggered aspect (catch) of situational interest usually occurs when students report their excitement immediately or during a specific intervention [42]. Generally, but not exclusively, it is externally supported [43]. Triggered and maintained situational interest runs on a continuum and, as advised by [44], effective instruction moves students onto the maintained phase as it is the key factor that encourages learning. Maintained situational interest (hold) is a more involved form of interest whereby 'individuals begin to forge a meaningful connection with the content of the material and realise its deeper significance' [45] (p. 2). This phase is exemplified by persistence over an extended period of time [43]. To maintain situational interest, the specific content has to be meaningful and important to the learner $[40,43,46]$. Given this, meaningful and relevant learning conditions are paramount to maintained situational interest [44].

\subsubsection{Attention}

As noted by a number of authors [29,30], attention is a core trait concomitant with hook instructional strategies. Attention refers to a selection of stimuli under the dominant control of behavior [47], and is a necessary precursor to information processing [48]. It is directly related to human performance and facilitates the focusing of the conscious mind [49]. Further, interest facilitates attention and alertness so that learning is more focused $[25,38,50]$.

Successful allocation of attention gives way to fluid information processing by reducing interferences [51]. A smooth processing is akin to a sense of flow whereby an individual is fully engaged with an activity, often accompanied by a sense of intrinsic enjoyment $[52,53]$. The deeper we process information on a cognitive level, the more attention 
we pay, and this translates to better learning [54]. Indeed, McCrory [31] and Jensen [55] state that it is a necessary condition for learning and achievement. Given this, attention is a vital component of successful educational environments. Efforts within instruction should therefore attempt to create an attention aware classroom [56].

\subsubsection{Engagement}

In terms of engagement, a distinction needs to be made between school engagement and engagement in learning $[57,58]$. This research is focused on engagement in learning grounded in the classroom context [59-61] as this type of engagement is deemed to be malleable through pedagogical interaction [62]. Engagement is regarded as a persistent and affective motivational state characterized by vigor and dedication [63]. Students who are engaged show augmented productivity and capacity for continuous knowledge acquisition [64]. Although there is little agreement in the literature pertaining to a definition or effective measure [37] of engagement, the majority of research has rested on a model with emotional, cognitive and behavioral facets $[62,65,66]$. Emotional and Cognitive Engagement are elaborated upon here due to their direct relevance to this study.

\section{Emotional Engagement}

Emotional engagement refers to the affective reactions of students in the classroom [31, $62,66,67]$. It encompasses reactions to instruction in either a positive or negative manner [62]. According to McCrory [31], there is a wide range of emotions that teachers can foster throughout their teaching. Curiosity, anticipation, uncertainty, surprise, understanding, wonder and amazement are components of good teaching that give pupils an emotional reward linked to the topic. Such feelings in class have been found between emotional engagement and achievement [37]. It is suggested by Hampden-Thompson \& Bennett [66] that these emotions experienced in class add meaning and potentially a deep value to the lesson content [62] rendering emotion as a pivotal factor in engaging students.

\section{Cognitive Engagement}

Cognitive engagement is a psychological construct in which mental effort is expelled on an academic task $[37,67]$. It is characterised by persistence in trying to understand a topic over a period of time [68]. Cognitive engagement incorporates cognitive activities commensurate with the lesson. The deeper a student processes information, the more likely it remains intact for future memory retrieval. The words 'deep' and 'shallow' describe a continuum of levels ranging from intensive learning to surface processing [69]. Cognitive engagement is recognized in class when students expend mental effort upon encountering learning tasks, and is often represented by persistence [70] in attempting to understand or master skills [62].

These theoretical constructs (Interest, Attention, Engagement) were considered throughout the hook design phase and are detailed in a recent paper by McHugh \& McCauley [9]. The student reaction relative to these hooks and the theoretical pillars are detailed within this paper.

\section{Materials \& Methods}

An interpretive paradigm with an eclectic qualitative approach was instigated as it allows for experimentation in complex social constructs [71]. Fostering dialogue and opinions through naturalistic research methods was central to the project. This research is exploratory, as there is little research reported on the design and implementation of hooks as an isolated component in the classroom, and in particular from the teacher perspective [1].

This research sits within a larger Design Based Research (DBR) methodology, which has shown success in creating a symbiotic conduit between pedagogy and educational technology [19,72-74]. DBR cycles start with a design. According to Wang \& Hannafin [74] (p. 16), 'Designers can adapt a mature theoretical framework or initiate a new one according to the purpose of the design and features of the setting'. As such, the researchers 
identified the theoretical elements of hooks (attention, interest and engagement) as design pillars, and took the physics video hooks to the 'test track' of the classroom [75]. The intention was to gather evidence from teacher interviews, researcher observation and researcher post reflection notes to identify if the hooks impacted student attention, interest and engagement.

\subsection{Participants \& Classroom Interventions}

An intervention approach was used as the research wants to identify successful and unsuccessful components $[14,76]$ of hook teaching and learning methods. Teachers are the gatekeepers of their classrooms [8] and have a keen insight into their students'/classes' unique behaviors. Although there are limitations to its sole use, observational research can provide insight about processes that other modes of assessment cannot, and this is particularly true when the construct of student interest is being researched [77]. Triangulation acts as a worthy validity instrument in this regard and data was collected through teacher interviews $(N=10)$, structured lesson observation and researcher journal documentation. The intervention took place in the classroom, as a naturalistic context for the instructional tool [78]. Each hook video has the same design structure and framework; hence, they are deemed comparable from a design perspective.

Ten teachers in ten different schools (post-primary/middle school) across the country were recruited for the study using a purposive sampling frame with a varying demographic across school type and location (urban/rural). Four male and six female teachers took part in the project with varying levels of experience. The teacher is central in the adoption of video in the classroom in terms of when and how to integrate the video, be it as supplementary material in a conventional course design, or implemented as a new instructional design that embraces video as a primary item [10]. Teachers were invited to use their instruction of choice to support the integration of the novel technology to support the associated response of interest and engagement. They agreed to implement their chosen methodology with any three hooks from Table 1 in three different lessons ( 1 hook per lesson) over a period of four months. The resulting thirty interventions involved 182 students (age 12-15). Teachers agreed to researcher observation in their third intervention, yielding an observation of ten lessons, $640 \mathrm{~min}(4 \times 40 \mathrm{~min} ; 6 \times 80 \mathrm{~min})$. Teachers were given freedom to design instruction around the hook, and as such, multiple teaching formats were recorded, and detailed in Table 2 below. In the observed lesson, some teachers used more than one of the strategies when teaching using their hook.

Table 2. Hook Teaching Strategy.

\begin{tabular}{ccc}
\hline Hook Teaching Strategy & Description & $\begin{array}{c}\text { Teachers Who Used the Hook Strategy } \\
\text { during Their Observed Lesson }\end{array}$ \\
\hline Pre/Post & $\begin{array}{c}\text { The teacher designed additional activities to } \\
\text { supplement the video. Students engaged in these } \\
\text { before and after the video hook }\end{array}$ & $\begin{array}{c}\text { Aisling; Bill; Catherine; Emma; James; } \\
\text { Richard }\end{array}$ \\
\hline Segmentation & $\begin{array}{c}\text { The teacher paused the video at key moments and } \\
\text { interjected with questions and activities } \\
\text { throughout the video hook. }\end{array}$ & Aisling; Denise; Eva \\
Guided/Structured IBL & $\begin{array}{c}\text { The video hook was used as a driver for IBL, } \\
\text { whereby students explored the same science in } \\
\text { their classroom using physical equipment. }\end{array}$ & Bill; Denise; Eva \\
\hline Post Revision Strategy & $\begin{array}{c}\text { The teacher used the video as a way of assessing } \\
\text { student understanding near the end of a lesson }\end{array}$ & Helen; Yvette \\
\hline
\end{tabular}

Teachers used multiple teaching formats [79] dominated by an inquiry methodology, placing the video hook technology at the middle and end of the lesson, where instruction necessitated its influence, as a para-hook. A para-hook is described as a short instructional 
strategy that augments students' situational interest and engagement at various time intervals other than lesson introduction [79]. In essence, the hook is parachuted into the lesson by the experienced teachers where they identify it as 'best fit'. It is an extension of traditional hook methodologies. Although pedagogy fluctuated, the video hooks remained constant and this paper reports on the observed student reaction of this para-hook methodology regarding the conceptual constructs of interest, attention and engagement.

In order to situate the design cycle reported in this paper within the larger study, the illustration below captures a summary methods plan, with design cycle 2 (DC2) positioned as center (Figure 1).

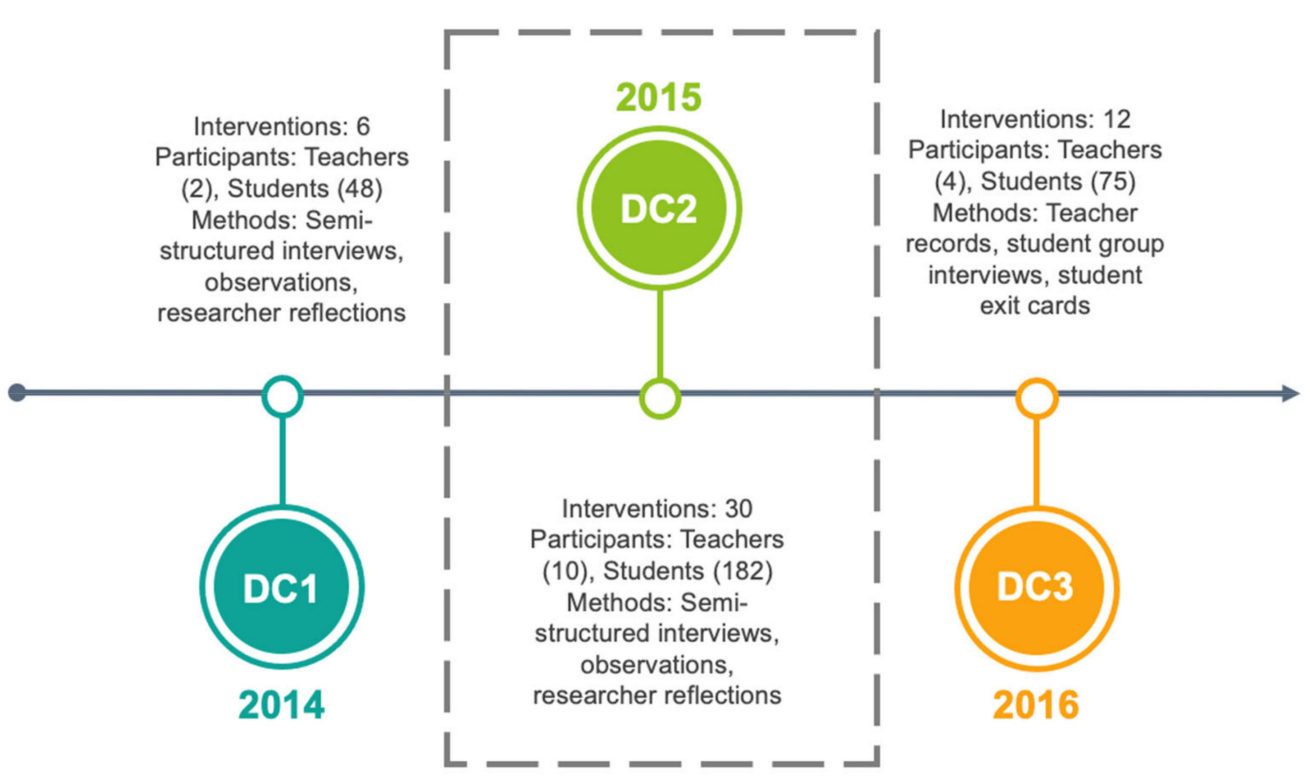

Figure 1. Methodology illustration of design cycle 2 (DC2) within the overarching study.

\subsection{Data Collection Methods}

The three data collection tools employed were classroom observations (10), semistructured interviews with teachers (10) and researcher reflection, after both former data collection methods (20). Semi-structured observations were employed in line with an observation schedule. In terms of observation protocol, the researcher sat at the back of the room to arouse as little influence/distraction on the students as possible.

According to Renninger \& Bachrach [77] observational methods are the only way to characterize interest and engagement in a naturalistic setting, particularly in terms of detail and understanding. More specifically, they are necessary to provide essential details when trying to understand processes that take place in the classroom $[65,80]$. Furthermore, it is positioned that the insight gained through observational methods is generally of more value to educators since they are concomitant with an insight into the context $[65,77]$. The observation schedule ensured that specific sections of the class were analyzed intensively, including:

- $\quad$ Factual and physical data: Teacher, Time and day of class, Year, School, Numbers in class (Boys/Girls), Location of class (Lab or classroom/other), Drawing of the layout of the classroom (plan), Specific topic being taught, Hook used, technology used to play hook, Time during class hook was used.

- Instruction/Pedagogy: Any teaching methods that linked to the hook used by teachers, before, during or after playing the video

- Students' affective state: Student reaction just before hook, Student reaction during hook, Students reaction immediately post hook, Student reaction throughout the lesson post hook. 
The challenging decision of the observer is in identifying what to watch and when. During an observation, a researcher's experiences identify certain characteristics as worthy of annotation. In support, the observation schedule (available in Appendix B) split descriptive factual data from inferences, hunches and reflective data. The final section of the observation schedule was open-ended to allow for the inclusion of field notes. The exact field note taking strategy employed was a combination of the salience hierarchy strategy and scratch notes as described by Wolfinger [81] and Sanjek [82], respectively. Further refinement took place through the separation of descriptive and reflective notes. Bodgan \& Biklen [83] make the distinction between descriptive field notes and reflective field notes. Descriptive notes aim to capture a slice of life. Descriptive aspects encompass the following categories: portraits of the subjects, reconstruction of dialogue, description of the physical setting, accounts of specific events, depiction of activities and the observer's behaviour [83]. In contrast, reflective field notes refer to a more personal account of events. They are highly subjective as the emphasis in on emotions, impressions and prejudices. Bodgan and Bilken [83] (p. 114) suggest to "let it all hang out". This is akin to a confession in which the inadequacies, likes and dislikes of the research need to be described. The purpose of this is to improve the notes as the researcher plays such a central role in the collection of data [83]. The separation of descriptive and reflective notes enhances the validity of the study by providing a self-checking method that can be revisited during the analysis of field notes. This was further enhanced through the creation of what Lather [84] calls 'face validity'. All observational records were typed and returned to teachers for verification, provoking a recycling process in which both the researcher and participant agree on the events that took place during the observation, lending further credence to findings.

Semi-structured interviews (17 open ended questions, available in Appendix A) were audio recorded and employed to ascertain teacher's perceptions of their lesson and the reaction of the students to the hook strategies. The interview schedule had four categories and the one considered in this paper is 'student behavior during the hook lesson'.

Pertaining to bias and truthful accounts from participants, teachers were aware that the interviewer was a former teacher. In light of this, the interviewer had a good understanding of the respondent's language and culture. This is particularly important in specialist areas (such as teaching) whereby nuances of language may infer meaning [85] and the establishment of a quick rapport is key [86]. Researcher reflections were documented after each interview and observation.

\subsection{Ethical Consideration}

The ethical implications of the study were taken into account before and during the research process. Given this, an ethical approval application was sent to the NUI Galway University Ethics Research Committee (ERC) in advance of the research and two additional amendments were sought during later design cycles to facilitate emerging modifications.

Pseudonyms were used throughout the study to protect teacher and student identity. It should be noted that observations were initially intended to be video recorded, however, this was not approved by the University Ethics Committee, as it was felt to be disruptive to classroom experience and unnecessary if scheduled observations could be employed. Moreover, follow up participant meetings revealed that teacher participants favored not being recorded. Thus, an observation protocol was enacted. Given that the content and design of the videos were greatly aligned with the curriculum and that the agreed data collection was not overly invasive or personal in terms of inquiry, the study was deemed ethical in nature and fit for purpose.

\subsection{Data Analysis}

The analysis framework employed in this study draws mostly from thematic analysis methods. Moreover, a more structured audit trail is developed with this type of analysis framework. Thematic analysis 'is a method for identifying, analyzing and reporting patterns (themes) within data.' [87] (p. 79). It is distinct from other analytical methods as it 
seeks to describe patterns across all data $[87,88]$. Although presented as a linear fashion below, the research analysis is a flexible progression [88]. A deductive approach to coding was implemented as this aligns with DBR methodologies where theoretical considerations are built into a design artefact before the collection of data.

Terry et al. [89] presents an iterative and flexible six stage approach to thematic analysis which was employed within this research. The process maneuvered through various levels of abstraction, which emphasized the evolution of interpretations and descriptions to higher logic levels. The adopted approach (Figure 2), being that of creating codes, categories and themes [90].

Pre-Coding

Data collection and transcription
First cycle coding

\section{Second cycle coding (categories)}

Theme development

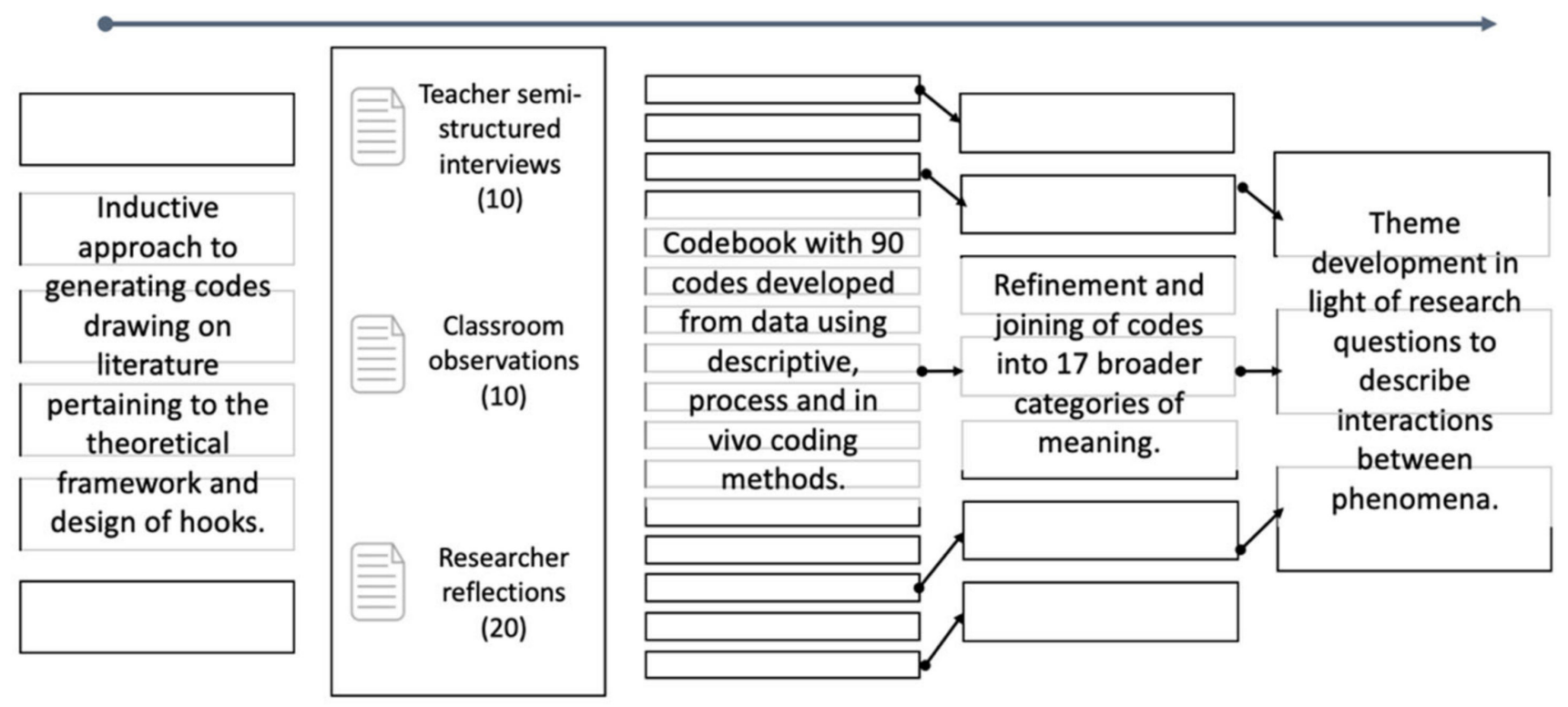

Figure 2. Illustration of the adopted approach of creating codes, categories and themes.

Embedded within a thematic framework, the precise amalgam analysis method was instigated throughout all design phases. This incorporated a deductive approach to coding. Elemental methods such as descriptive, process and in vivo codes, as outlined by Saldaña [91], were used for first cycle coding. Once unique codes were identified, they were placed in a codebook with a descriptor and an example. Building on this, second cycle coding emerged from the first cycle, but lifted the data in categories and subcategories with similarities and relationships based on theme, content and subject and relevant stakeholder. First cycle coding was conducted by hand while second cycle coding was completed using NVivo 10 software. Patterns that were developed lent to emergent themes that provided the foundation for the results of the study [92].

It should also be noted that all coding was conducted by the primary researcher and validated by the research team. The establishment of inter-rater reliability through multiple coders was not deemed appropriate.

\section{Results and Discussion}

The impact of the video hooks on the classroom and in particular the student reaction is explored in the following section. Supported by qualitative evidence from teacher interviews, research observation documents (where student reaction is reported upon relative to 'majority reaction of the class group'), and post-intervention researcher notes.

Findings are presented within two categories: triggered student reaction and maintained student reaction. Initial analysis revealed evidence and a clear distinction between 
triggered and maintained student interest. Further exploration of the data and theoretical constructs revealed an alignment between 'attention-triggered situational interestemotional engagement' and 'attention-maintained situational interest-cognitive engagement', and thus a revised dyad of triggered and maintained student reaction arose. It should be noted, however, that although one construct may ignite another, that the direction of this ignition is not always clear, and as the discussion will reveal, attention can ignite interest and vice versa. As a result, the constructs are not easily discussed in isolated sub-sections.

In relation to scholarship in the field, an example is given here in relation to the connected constructs of attention-triggered situational interest-emotional engagement (Figure 3):

Many authors agree with the description of triggered interest as a type of emotional engagement $[5,8,16,28,29,40,60,86,100]$. Rotgans \& Schmidt [89] describe situational interest as an affective or emotional response to instruction, drawing a clear alliance between triggered SI and emotional engagement. Further to this Subramaniam [103] denotes situational interest as an affective reaction triggered by an object.

Figure 3. An example of the theoretical alignment of Triggered Student Reaction.

Relative to the two categories, the image below (Figure 4) encapsulates a reminder of their theoretical interpretation, drawn from the conceptual framework above:

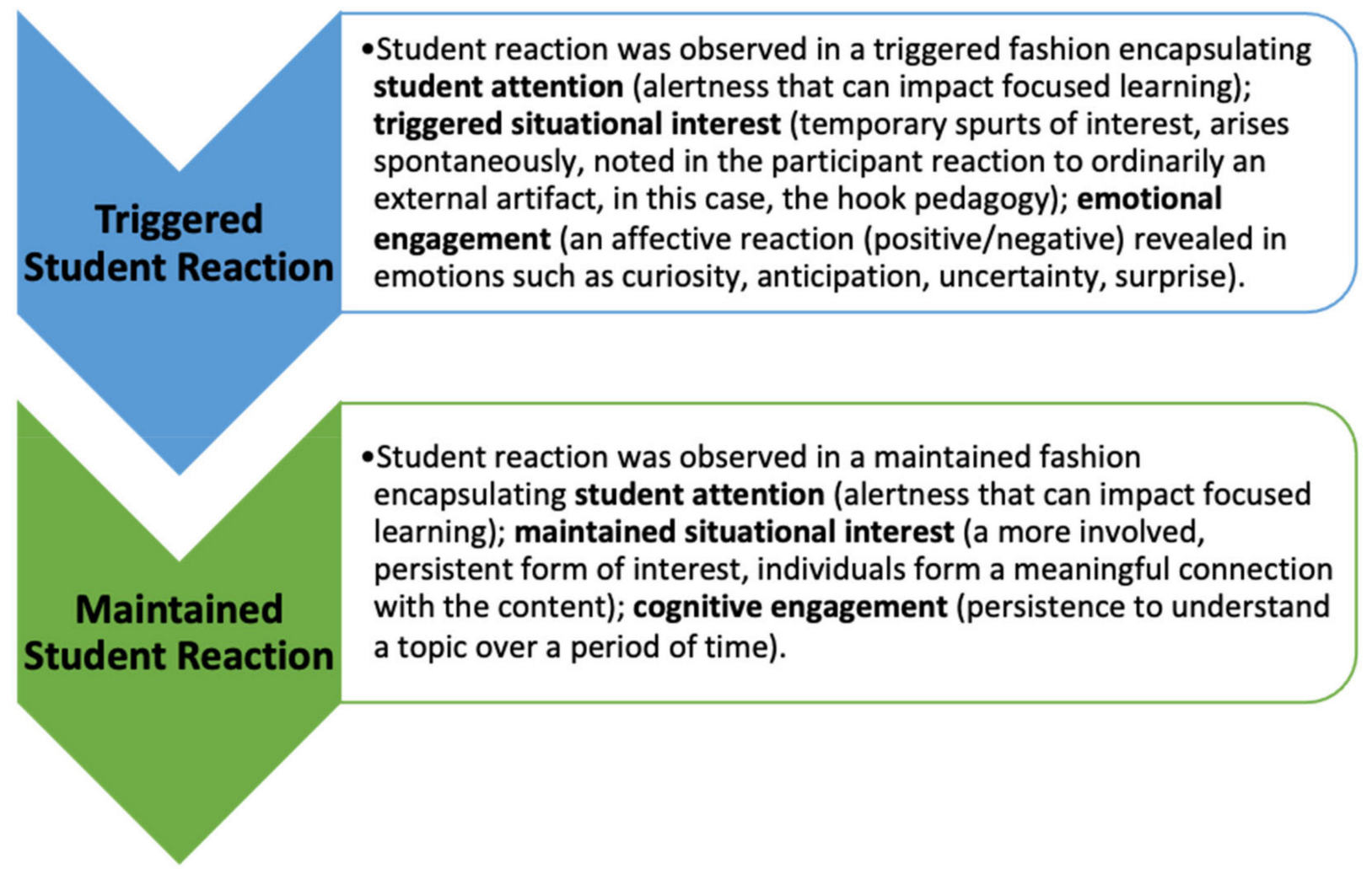

Figure 4. Theoretical Summary of Triggered and Maintained Student Reaction.

\subsection{Triggered Student Reaction}

The initial observable reaction to the video content by the student body encompassed the three constructs of attention (an alert focus), engagement (disbelief, curiosity) and heightened interest. (recorded as a majority reaction in nine of ten observations; noted by eight of the teachers). Teacher's descriptive comments on their classes and observed 
student reaction over the next few paragraphs provide evidence of this reaction; the focused attention, the comments of uncertainty catalyzing curiosity, and the interest to learn more:

Catherine: ... like I heard one of the girls and I know she is extremely, extremely smart, she em, the bit about the Blu-Tak, she went 'o my god, look at that ...' (Interview IC15)

Yvette: When they see something different then it really gets them to kind of like, why did that happen and to get them I suppose, yeah generate their interest in the topic and wanting to find out more ... That did not happen the way I thought it was going to happen. (Interview IY15)

James: There's ones there like, say the centre of gravity one, they didn't believe that one worked. (Interview IY15)

Yvette: They will kinda say, look it, you can see it there with your eyes, like, and its creating that conflict in their heads. (Interview IY15)

Aisling: but I think that's it, I think it's the fact that it is not the result they are expecting so they, they might think the oil will float, but most think that maple syrup will as well because it looks kind of similar, [ . . ] whereas when it doesn't, they're like, 'why is that?' (Interview IY15)

Aisling: I mean they do see things sometimes and they will be like a no that's not right or I don't feel that's the case ... (Interview IA15)

While the students' engaged with the content of the video hook, they were drawn into attempting to figure out the unusual phenomena. Students' initial verbal reactions were 'Wow!', 'Cool!', 'Yes!' and more commonly 'What?' These reactions typically lasted between 10 and $30 \mathrm{~s}$ with teachers having to settle the class group down afterwards. Typical reactions by students when the video hooks were played were:

Class 1:

Student A: What!?

Student B: No! (disbelief) (Observation ROD15)

Class 2:

Student A: ya, that's cool, it's like a jet.

Student B: Can we do that tomorrow miss? (Observation ROE215) Moreover, student's reactions 'bounced' off one another with initial vocalized reactions quickly turning to small local conversations among students about the content, socially reaffirming their reaction with others. We position that the observed 'What?' moments represent a positive engagement with the video content and have the potential to represent triggered situational interest [31]. Moreover, multiple authors [46,77] assert that the triggering of interest can establish the initiation of engagement. A similar reaction from class 2 above was also present in nine of the ten observations. Students wanted to 'see if for themselves', and a desire to try the observed experiments was common. Often students expressed a knowledge gap through their questions, wanting to replay the video or conduct the experiment for themselves. These seeking instances are indicative of situational interest which usually occur when students report their excitement immediately or during a specific intervention [42] and this is evidenced on numerous occasions by 'What?' moments. In a study by Muldner et al. [93], 'yes' moments were observed when students expressed excitement or pleasure while engaged in a lesson. The 'yes' moment was a positive affirmation of interest that in turn improved performance and cognitive function [93]. The researchers posit that the 'What?' moments, noted previously, represent a positive affirmation of interest with the video content [31] akin to 'yes' moments [93], yet also catch student attention and awaken emotional engagement.

Emotional engagement refers to students' affective reactions such as anxiety, interest, happiness or enjoyment [66]. According to McCrory [31], there is a wide range of positive emotions that teachers can foster through their teaching. Curiosity, anticipation, 
uncertainty, surprise, understanding, wonder and amazement are components of good teaching that give pupils an emotional reward linked to the topic that should augment levels of engagement and interest [31]. Arnone et al. [94] describe curiosity as a construct that incorporates both interest and engagement with Krapp [36] indicating that the first occurrence of triggered situational interest is characterized by curiosity. According to Luce \& Hsi [95] (p. 73) 'The learner can express curiosity as fleeting observations of wonderment and noticing inconsistencies or finding novelty in an object or through activity'. Further to this, according to Renninger \& Bachrach [77] (p. 59), 'triggering interest and supporting its development are likely to be essential to whether an engagement intervention will have the power to change behaviour'. Changes in student demeanor, facial expression and body language occurred instantaneously and were recorded in the observation schedule. The extract below encompasses both physical and verbal signals recorded during the triggered phase.

The students watch the second hook on atmospheric pressure. Some of the student's jump when the can gets crushed in the video. Some say 'class' [colloquial student term for brilliant].

(Observation ROR15)

Another group of students reacted in the following way to the atmospheric pressure hook.

Student A: Is that just cold water?

Student B: Whoa!

Student C: What? (Observation ROJ15)

A range of emotions may have been felt and displayed by the students at the expressive 'What?' moment [31], however, the strongest emotions present were that of curiosity and triggered interest. Curiosity is described by Shenaar-Golan \& Gutman [96] as an ambiguity between new and previous knowledge, evoked through complexity, novelty and unfamiliarity. Loewenstein [97] agrees with such views and describes curiosity as a deprivation-based emotion that occurs when an individual recognizes a gap in their knowledge. Within the students' fleeting observation of the video hook, they were drawn into attempting to figure out each unusual phenomenon with questions such as 'Is that just cold water?' or 'Can we do that?' as the video is being played. These questions illustrate that the student had an intense curiosity to acquire an understanding of what they had just observed, to satisfy their knowledge gap. Teachers expressed similar sentiments in terms of an immediate emotional engagement with the content, the overarching emotions being curiosity and interest.

Aisling: ... they loved the density tower, o my god, they absolutely loved it, they thought it was really cool, and as I said they were kinda like, we want to do that. (Interview IA15)

Emma: a video is at face value, a video and whatever they get out of it [ . . . I just didn't expect them to be so into it'. (Interview IE115)

The teachers' language and sentiments indicate that the students' reaction was plain to see, although somewhat unexpected, as they did not have similar reactions with other videos. The emotional engagement expressed during the triggered phase was pervasive in observed lessons where triggered situational interest was seen to initiate engagement $[46,77,98]$.

Rotgans \& Schmidt [99] align their research of knowledge deficits in terms of situational interest. The authors compare the development of epistemic curiosity and the development of situational interest as concepts that develop in parallel. That is, they denote the same construct and process [100]. This expands on previous work by Arnone et al. [94], who define curiosity as a construct that is concomitant with both interest and engagement. The authors note that developing curiosity is often discussed in the literature as the primary way of triggering situational interest [94] and evidence of the triggering of these constructs was evident across $90 \%$ of the para-hook lesson. 
Indeed, many authors agree that the description of interest is not something that is developed by engagement, or happens alongside it, but that it is a type of emotional engagement $[25,37,57,62,77,94,101-103]$. Rotgans \& Schmidt [24] describe situational interest as an affective or emotional response to instruction. Subramaniam [104] denotes situational interest as an affective reaction triggered by an object. This indicates that interest can also be defined as a form of emotional engagement. It is evident that the constructs are inherently connected in the literature, as they are here in their reactive form to the para-hook teaching.

From a temporal perspective, the next noticeable trait of the triggered interest phase which directly followed the 'What?' moment was a heightened state of attention from the students. Similar to other aspects of the triggered phase, this was something that visibly manifested itself during observations.

Many of the students sit up during the video, especially the ones on the back. (Observation ROR15)

The students are really paying attention during the video, they are sitting up in their chairs and they seem to be very interested. The students seem to be answering the questions that are placed on the screen and in the video, they sometimes look at each other and attempt to explain the answers to each other. (Observation ROC15)

The data shows how students sat up in their seats and moved their heads in an attempt to get a better view of the screen once their interest had been triggered. This was not the same as their initial reaction to the start of the video which is typified by initial attention and quiet concentration. The increased levels of attention, be they verbal or physical, during the hook lesson, is a key indicator of triggered situational interest [45]. Eight out of ten teachers directly referenced increased attention amongst the class relative to student initial reaction.

Richard: Definitely attention ... immediately afterwards you noticed that they were, they were, they got into the activity a lot quicker than they would have usually you know they would spend a bit of time and be half a chat and you would have a few minutes gone before everybody would be settled to it (Observation ROC15)

This observed reaction is in line with Rotgans \& Schmidt [24] who states that situational interest is an immediate affective response that focuses one's attention on a task. Flowerday \& Shell concur [105] (p. 135) stating that situational interest can be 'instrumental in catching attention'. A number of other authors agree on the definitive relationship between attention and interest [98,106-109]. Attention involves heightening the attentive responses of individuals due to their environment and refers directly to the initiation of interest [45]. As such, increased attention can also be defined as indicators of triggered student interest [45]. Head and bodily movements (as noted above) are typical of attention and interest as it aids tracking of both objects and sounds [110], something that is omnipresent in video. Interest facilitates attention and alertness so that learning is more focused, and pupils may observe something they otherwise would have missed $[25,38,50]$ and this is something students were actively doing in class. Renninger \& Bachrach [77] agree with the connection between the constructs yet includes engagement in asserting that both interest and engagement can be triggered by something that catches the attention of learners. Therefore, again, as evidenced in the literature, and in practice, in reaction to the para-hook methodology, the three conceptual pillars of interest, engagement and attention actuated and are intrinsically allied.

\subsection{Maintained Student Reaction}

Building upon the triggered reaction, students' interest was upheld or maintained in many instances beyond the initial lesson trigger. The data reveals that students were extremely interested in the phenomena illustrated in the hook video. In some instances, initial signals of an enduring disposition were noted. Teacher interviews revealed that a 
maintained reactive phase was apparent, as students referenced the hook videos in both homework and tests, when discussion was not deliberately sought.

Denise: Even then for homework I was giving an example of friction? and when I was going around looking at the copies some of them had said 'if you put a knife into rice' (referring to content from hook video).

(Interview ID15)

Aisling: I mean the fact that they can actually relate the stuff they saw in the videos to a test that they did a week later, I mean, I mean that is showing a long-term impact and actually I could see based on their answers, they were referencing the video.

(Interview IA15)

Another teacher described a situation in which a student went home and built one of the props from the video so the class could recreate the hook the following day.

Emma: ... well I had one massive impact and it was the energy conversion one, the weakest student in the class and eh, he was the person who came up with the can [ ... ] the next day and so, it has given him massive, I suppose the effect it had on him was massive because the rest of them know he's very weak because it's quite a strong class and he's the weakest. He has, he is better at practical work and he's so quiet and there he was coming in with the object that everyone else could use then.

(Interview IA215)

This sentiment represents a positive expression of interest by the student, with some markers towards maintained interest, with the student wishing to re-engage and physically build the hook components. In terms of maintained situational interest, Hidi and Renninger [43] reference the application of content in new locations e. g. student applying their knowledge in home situations, and or in different lessons. Moreover, Klassen and Klassen [111] (p. 135) argue ' ... interest arises from an emotional response to certain kinds of stimuli in the learning episode and consists of increased and persistent attention to the interesting situation accompanied by increased cognitive activity and the desire to re-engage'. Cognitive engagement in terms of artefact reconstruction is evident in this example, and the willingness to engage further with the hook concept.

Similar to how an emotional and attentive response characterized the triggering phase, a cognitive response may offer some indicators towards a maintained phase. Cognitive engagement can be characterized as a psychological state in which students exert extra mental effort and persistence to understand a topic over a period of time. It can be further operationalized by interactions with teachers in class [24]. Cognitive engagement refers to the extent students expend mental effort when they encounter learning tasks. It is often represented by persistence $[43,62,70]$.

Teacher interviews reveal some examples of this cognitive engagement with the hook. In many lessons, students were eager to re-engage with the content through intense questioning. Rotgans \& Schmidt [99] argue an alignment from emotional to cognitive engagement when they assert that students who become emotionally engaged through curiosity or any other emotion will put in the effort to learn difficult content. That is, a triggered foundation may lead towards a maintained situation. Cognitive engagement through self-initiated student questioning was evident throughout the para-hook lessons and evidenced in teacher and researcher observations:

Richard: ... the level of the questions that they asked were much better than other lessons, I think the way that they, the way they worded their questions, maybe that they were just thinking about things more and that would be, not at all ... be reflective of what you would usually get back... (Interview IR15)

Catherine: ... what was even more interesting is what came from it (the hook), the questions that they had, like: what if? (Interview IC15) 
The students are asking excellent questions. The questions were derived from the hook and are about forces. (Observation ROR15)

Yet, they are still working hard trying to do it (perform the experiment) in class [... ] they simply want to achieve a goal they have observed and prove it to themselves and the rest of the class. (Observation OD15)

In addition, everyone was able to make a prediction based upon their intuitive knowledge. Students let out shouts of 'ya' and 'yes' as they were proven correct. (Reflection ORA15)

Further, in terms of cognitive engagement, in Emma's teacher interview she commented on how to her surprise, the majority of her students remembered every detail of the hooks:

Emma: I went through it (the hook) and they remembered every detail. They spotted even things like there was hot water put in, into the can, down to, they noticed that it was one third of the volume of the can that was put in. (Interview IE115)

Emma: They had a high level of knowledge and they were able to spot it all and they were able to apply other knowledge to the video, so it was consolidating all their knowledge. (Interview IE115)

As illustrated above, students exhibited excellent recall in terms of the video content. Below, a researcher reflection corroborates this theory.

One thing I couldn't believe is how much information the students extracted from the video. They answered questions about the video more efficiently and faster than any other questions that were asked during class. The students knew every fact about the video, and I found it very surprising. For example, they remember all of the objects that dropped into the density tower, such as the ping pong ball and the nail. (Reflection ORC15)

This data substantiates that the students were effective at comprehending and retrieving aspects of the video content [22,112]. Taking into account both the higher-level questions and the students' memory retrieval, we argue that the seedlings of a maintained reactive phase are present, characterized by maintained situational interest and augmented cognitive efforts [113] and cognitive persistence.

\section{Conclusions}

With video becoming more commonplace in the classroom [114] and incremental scholarly evidence of video's capability of enhancing the learning experience [115], this paper provides an observational narrative of student reaction to video hooks, or video para-hooks (as teachers used the video hooks at various intervals in the lesson, other than lesson introduction). The student reaction over a four-month period involving thirty lessons is elucidated with regard to the development of triggered and maintained student reaction concomitant with facets of attention, interest (triggered situational, maintained situational respectively) and engagement (emotional, cognitive respectively).

As a brief synopsis of findings, firstly, the link between interest and engagement was overt and readily observable in this research, in particular the exhibition of triggered situational interest and emotional engagement, concomitant with augmented and instantaneous attention levels [45]. This immediate response to the para-hook instructional method was recognizable in class with students verbally expressing their awe, wonder and disbelief while physically expressing their need to get a better view of the screen and socially interact with their peers. This reaction gave way to a more controlled cognitive engagement and maintained situational interest with the para-hook content. This outcome signals a significant contribution to the field and to practitioners and curriculum designers. Current hook literature advocates hooks to be used at lesson introduction. This research refutes this solitary event in place of hooks being incorporated into the wider instruction of a 
lesson. Teachers viewed the para-hooks as adoptable and adaptable pieces of educational technology to be used in instruction, revision and inquiry learning scenarios. Moreover, at the fulcrum of educational change, in light of Covid-19 imposition on our classrooms, the pedagogy described here could be helpful to support science instruction in in-person or remote learning scenarios.

Furthermore, in terms of methodology, a clear depiction is given of the observation methodology used to collate and document the complex constructs evident in the learning ecology, and as few, if any, examples of lesson hook observation are evident in the literature, this research provides a further contribution here.

Finally, regarding research limitations, although the observations were comprehensive, and correlated with teacher perception of classroom participation, if video evidence had been approved by the ethics board, then further quantitative evidence may have been forthcoming. Further, a replication of this study on a larger scale and/or using a longitudinal scenario could lend further credence to the results, in particular in relation to the persistent state of student reaction. As such, further research is warranted in this field.

Author Contributions: Conceptualization, V.M. and M.M.; data curation, M.M.; formal analysis, M.M.; Investigation, M.M.; methodology, V.M. and M.M.; validation, V.M.; visualization, V.M. and M.M.; writing—original draft, V.M. and M.M.; writing—review \& editing, V.M.; All authors have read and agreed to the published version of the manuscript.

Funding: This work has been funded by the NUI Galway Hardiman Scholarship.

Conflicts of Interest: The authors declare no conflict of interest.

\section{Appendix A. Teacher Interview Schedule}

General/Teaching strategy

1. What are your thoughts on the hooks project as a whole? (Do they work, worthy resource?)

2. Describe the impact that the video hooks had on your teaching, if any?

3. Can you describe the teaching strategy that you employed in association with the hook? (Why did you use this strategy?) (Has this strategy changed over the course of the project?)

Video

4. What process do you go through when deciding on what videos to use in class?

5. How do you decide on how to use the video in class?

6. Do you use them as hooks or for other applications?

Application

7. Would you have preferred to perform a live demo of the video hook content? Student

8. Describe the impact, if any, that the video hooks had on your students?

9. Were there any differences in the way hooks impacted on stronger vs weaker students?

10. The video hooks are designed to have an influence on attention, interest and engagement. Did you notice this influence over the course of the study or would you use another word to describe the impact?

11. How long do you think any impact lasted on the class?

12. The videos are characterised as hooks; do you think their main purpose is as a hook or do you think it could be used as a revision tool or a transition tool in class?

Time

13. If you used the videos on a regular basis, do you think that the video hooks would work as a long-term method of developing sustained attention, interest or engagement in science or physics? 


\section{Design}

14. How would you improve the video hooks?

15. What are the worst features about the video hook design?

16. What are the best features about the video hook design?

17. If you could design you own video hook, what would you make and what would you include?

\section{Appendix B. Student Observation Schedule}

Observation Schedule

Notes-Reflective/Analysis

Teacher:

School:

Date:

Time of class:

Location of class:

Numbers in class:

Male:

Female:

Specific topic being taught:

Is this lesson the start of a new topic? $\mathrm{Y} / \mathrm{N}$

Hook used:

Time at which hook was used:

What technology was used to play the hook?

Pre-teaching method(s):

Teaching method(s) employed with hook:

\section{References}

1. Cian, H.; Marshall, J.; Qian, M. Inquiry Classroom Patterns of Student Cognitive Engagement: An Analysis Using Growth Curve Modeling. J. Sci. Teach. Educ. 2018, 29, 326-346. [CrossRef]

2. Watkins, J.; Mazur, E. Retaining Students in Science, Technology, Engineering, and Mathematics (STEM) Majors. J. Coll. Sci. Teach. 2013, 42, 36-41. Available online: www.jstor.org/stable/43631580 (accessed on 3 June 2021).

3. Guzey, S.S.; Roehrig, G.H. Integrating educational technology into the secondary science teaching. Contemp. Issues Technol. Teach. Educ. 2012, 12, 162-183. Available online: https:/ / www.learntechlib.org/primary/p/39130/ (accessed on 3 June 2021).

4. Tan, E.; Pearce, N. Open education videos in the classroom: Exploring the opportunities and barriers to the use of YouTube in teaching introductory sociology. Res. Learn. Technol. 2011, 19. [CrossRef]

5. Zhang, D.; Zhou, L.; Briggs, R.O.; Nunamaker, J.F., Jr. Instructional video in e-learning: Assessing the impact of interactive video on learning effectiveness. Inf. Manag. 2006, 43, 15-27. [CrossRef]

6. Roure, C.; Méard, J.; Lentillon-Kaestner, V.; Flamme, X.; Devillers, Y.; Dupont, J.P. The effects of video feedback on students' situational interest in gymnastics. Technol. Pedagog. Educ. 2019, 28, 563-574. [CrossRef]

7. McCauley, V.; Davison, K.; Byrne, C. Collaborative lesson hook design in science teacher education: Advancing professional practice. Ir. Educ. Stud. 2015, 34, 307-323. [CrossRef]

8. McHugh, M.; McCauley, V. Designing Physics Video Hooks for Science Students. Phys. Educ. 2016, 51, 015015. Available online: http:/ /iopscience.iop.org/article/10.1088/0031-9120/51/1/015015/meta (accessed on 3 June 2021). [CrossRef]

9. McHugh, M.; McCauley, V. By Hook or by Crook: Designing physics video hooks with a modified ADDIE framework. J. Appl. Instr. Des. 2020, 9. [CrossRef]

10. Santos Espino, J.M.; Afonso Suárez, M.D.; González-Henríquez, J.J. Video for teaching: Classroom use, instructor self-production and teachers' preferences in presentation format. Technol. Pedagog. Educ. 2020, 29, 147-162. [CrossRef]

11. Bakker, A.; van Eerde, D. An introduction to design-based research with an example from statistics education. In Approaches to Qualitative Research in Mathematics Education; Springer: Berlin/Heidelberg, Germany, 2014; pp. 429-466.

12. Brown, A.L. Design experiments: Theoretical and methodological challenges in creating complex interventions in classroom settings. J. Learn. Sci. 1992, 2, 141-178. [CrossRef]

13. Collins, A. Toward a design science of education. In New Directions in Educational Technology; NATO ASI Series; Scanlon, E., O'Shea, T., Eds.; Springer: Berlin/Heidelberg, Germany, 1992; pp. 15-22.

14. McHugh, M.; McCauley, V.; Davison, K.; Raine, R.; Grehan, A. Anchoring Ocean Literacy: Participatory iBook Design within Secondary Science Classrooms. Technol. Pedagog. Educ. 2020, 29, 89-107. [CrossRef]

15. Van den Akker, J.; Gravemeijer, K.; McKenney, S.; Nieveen, N. Educational Design Research; Routledge: London, UK, 2006. 
16. Flynn, N.; Keane, E.; Davitt, E.; McCauley, V.; Heinz, M.; MacRuairc, G. 'Schooling at Home' in Ireland during COVID-19: Perspectives and Experiences of Parents, Young People and Children. Ir. Educ. Stud. 2021. [CrossRef]

17. Tejedor, S.; Cervi, L.; Pérez-Escoda, A.; Tusa, F.; Parola, A. Higher Education Response in the Time of Coronavirus: Perceptions of Teachers and Students, and Open Innovation. J. Open Innov. Technol. Mark. Complex. 2021, 7, 43. [CrossRef]

18. Tejedor, S.; Cervi, L.; Pérez-Escoda, A.; Jumbo, F.T. Digital Literacy and Higher Education during COVID-19 Lockdown: Spain, Italy, and Ecuador. Publications 2020, 8, 48. [CrossRef]

19. Amiel, T.; Reeves, T.C. Design-based research and educational technology: Rethinking technology and the research agenda. J. Educ. Technol. Soc. 2008, 11, 29-40. Available online: http:/ / www.jstor.org/stable/jeductechsoci.11.4.29 (accessed on 3 June 2021).

20. Gilbert, J.K. Visualization in Science Education; Springer Science Business Media: Berlin/Heidelberg, Germany, 2005.

21. Mariooryad, S.; Kannan, A.; Hakkani-Tur, D.; Shriberg, E. Automatic Characterization of Speaking Styles in Educational Videos. IEEE International Conference on Acoustics, Speech and Signal Processing Proceedings (ICASSP), Florence, Italy, 4-9 May 2014; pp. 4848-4852. Available online: https:/ / ieeexplore.ieee.org/document/6854523 (accessed on 3 June 2021).

22. De Jong, T. Cognitive load theory, educational research, and instructional design: Some food for thought. Instr. Sci. 2010, 38, 105-134. [CrossRef]

23. Mayer, R.E. Cognitive theory of multimedia learning. Camb. Handb. Multimed. Learn. 2005, 41, 31-48. [CrossRef]

24. Rotgans, J.I.; Schmidt, H.G. Cognitive engagement in the problem-based learning classroom. Adv. Health Sci. Educ. 2011, 16, 465-479. [CrossRef]

25. Bergin, D.A. Influences on classroom interest. Educ. Psychol. 1999, 34, 87-98. [CrossRef]

26. Broughton, S.H.; Sinatra, G.M.; Reynolds, R.E. The nature of the refutation text effect: An investigation of attention allocation. J. Educ. Res. 2010, 103, 407-423. [CrossRef]

27. Jewett, J.W., Jr. Hook your students! Phys. Teach. 2013, 51, 442. [CrossRef]

28. Marinchech, J. A Great Teacher Begins with a Hook. Available online: https://suite101.com/a/a-great-teacher-begins-lessonswith-the-hook-method-a255945 (accessed on 3 June 2021).

29. Hunter, M. Mastery Teaching: Increasing Instructional Effectiveness in Elementary and Secondary Schools, Colleges, and Universities; Corwin Press: Thousand Oaks, CA, USA, 1994.

30. Lemov, D. Teach Like a Champion: 49 Techniques That Put Students on the Path to College (K-12); John Wiley Sons: Hoboken, NJ, USA, 2010.

31. McCrory, P. Developing interest in science through emotional engagement. In ASE Guide to Primary Science Education; Harlen, W., Ed.; ASE: Hatfield, UK, 2011; Draft Chapter, pp. 94-101. Available online: https:/ / www.learndifferently.com/ (accessed on 3 June 2021).

32. Riendeau, D. Delightful Beginnings. Phys. Teach. 2013, 51, 380. [CrossRef]

33. Krapp, A.; Prenzel, M. Research on interest in science: Theories, methods, and findings. Int. J. Sci. Educ. 2011, 33, 27-50. [CrossRef]

34. -Hoffmann, L. Promoting girls' interest and achievement in physics classes for beginners. Learn. Instr. 2002, 12, 447-465. [CrossRef]

35. Joseph, D.; Nacu, D.C. Designing interesting learning environments when the medium isn't enough. Converg. Int. J. Res. Into New Media Technol. 2003, 9, 84-115. [CrossRef]

36. Krapp, A. An educational-psychological conceptualisation of interest. Int. J. Educ. Vocat. Guid. 2007, 7, 5-21. [CrossRef]

37. Sinatra, G.M.; Heddy, B.C.; Lombardi, D. The challenges of defining and measuring student engagement in science. Educ. Psychol. 2015, 50, 1-13. [CrossRef]

38. Schraw, G.; Flowerday, T.; Lehman, S. Increasing situational interest in the classroom. Educ. Psychol. Rev. 2001, 13, 211-224. [CrossRef]

39. Flowerday, T.; Schraw, G.; Stevens, J. The role of choice and interest in reader engagement. J. Exp. Educ. 2004, 72, 93-114. [CrossRef]

40. Mitchell, M. Situational interest: Its multifaceted structure in the secondary school mathematics classroom. J. Educ. Psychol. 1993, 85, 424. [CrossRef]

41. Tsai, Y.-M.; Kunter, M.; Lüdtke, O.; Trautwein, U.; Ryan, R.M. What makes lessons interesting? The role of situational and individual factors in three school subjects. J. Educ. Psychol. J. Educ. Psychol. 2008, 100, 460. [CrossRef]

42. Palmer, D. Research Report: Situational interest and the attitudes towards science of primary teacher education students. Int. J. Sci. Educ. 2004, 26, 895-908. [CrossRef]

43. Hidi, S.; Renninger, K.A. The four-phase model of interest development. Educ. Psychol. 2006, 41, 111-127. [CrossRef]

44. Lavonen, J.; Byman, R.; Juuti, K.; Meisalo, V.; Uitto, A. Pupil interest in physics: A survey in Finland. Nord. Stud. Sci. Educ. 2005, 1, 72-85. [CrossRef]

45. Linnenbrink-Garcia, L.; Durik, A.M.; Conley, A.M.; Barron, K.E.; Tauer, J.M.; Karabenick, S.A.; Harackiewicz, J.M. Measuring situational interest in academic domains. Educ. Psychol. Meas. 2010, 70, 647-671. [CrossRef]

46. Magner, U.I.; Schwonke, R.; Aleven, V.; Popescu, O.; Renkl, A. Triggering situational interest by decorative illustrations both fosters and hinders learning in computer-based learning environments. Learn. Instr. 2014, 29, 141-152. [CrossRef]

47. Berlyne, D.E.; Ditkofsky, J. Effects of novelty and oddity on visual selective attention. Br. J. Psychol. 1976, 67, 175-180. [CrossRef] 
48. Anderman, E.M.; Noar, S.M.; Zimmerman, R.S.; Donohew, L. The need for sensation as a prerequisite for motivation to engage in academic tasks. In Advances in Motivation and Achievement, Volume 13: Motivating Students, Improving Schools: The Legacy of Carol Midgley; Maehr, M.L., Pintrich, P.R., Eds.; Elsevier: San Diego, CA, USA, 2004.

49. Ainley, J.; Luntley, M. The role of attention in expert classroom practice. J. Math. Teach. Educ. 2007, 10, 3-22. [CrossRef]

50. Kerger, S.; Martin, R.; Brunner, M. How can we enhance girls' interest in scientific topics? Br. J. Educ. Psychol. 2011, 81, 606-628. [CrossRef]

51. Rosengrant, D.; Hearrington, D.; Alvarado, K.; Keeble, D. Following student gaze patterns in physical science lectures. In AIP Conference Proceedings; American Institute of Physics: College Park, MD, USA, 2012; Volume 1413, pp. 323-326. [CrossRef]

52. Csikszentmihaly, M. Creativity:flow and The psychology of Discovery and Invention; Harper Collins: New York, NY, USA, 1996.

53. Eastwood, J.D.; Frischen, A.; Fenske, M.J.; Smilek, D. The Unengaged Mind Defining Boredom in Terms of Attention. Perspect. Psychol. Sci. 2012, 7, 482-495. [CrossRef]

54. Heath, R.G. Emotional engagement: How television builds big brands at low attention. J. Advert. Res. 2009, 49, 62-73. [CrossRef]

55. Jensen, E. Brain-Based Learning: The New Paradigm of Teaching; Corwin Press: Thousand Oaks, CA, USA, 2008.

56. McVay, J.C.; Kane, M.J. Why does working memory capacity predict variation in reading comprehension? On the influence of mind wandering and executive attention. J. Exp. Psychol. Gen. 2012, 141, 302. [CrossRef]

57. Fredricks, J.A.; Blumenfeld, P.; Friedel, J.; Paris, A. "School engagement”. In What do Children Need to Flourish? Conceptualizing and Measuring Indicators of Positive Development; Moore, K.A., Lippman, L.H., Eds.; Springer: New York, NY, USA, 2005 ; pp. 305-321.

58. Harris, L. Secondary teachers' conceptions of student engagement: Engagement in learning or in schooling? Teach. Teach. Educ. 2011, 27, 376-386. [CrossRef]

59. Bain, K. What makes great teachers great. Chron. High. Educ. 2004, 50, B7-B9.

60. Oliveira, A.W. Engaging students in guided science inquiry discussions: Elementary teachers' oral strategies. J. Sci. Teach. Educ. 2010, 21, 747-765. [CrossRef]

61. Smart, J.B.; Marshall, J.C. Interactions between classroom discourse, teacher questioning, and student cognitive engagement in middle school science. J. Sci. Teach. Educ. 2013, 24, 249-267. [CrossRef]

62. Fredricks, J.A.; Blumenfeld, P.C.; Paris, A.H. School engagement: Potential of the concept, state of the evidence. Rev. Educ. Res. 2004, 74, 59-109. [CrossRef]

63. Wefald, A.J.; Downey, R.G. Construct dimensionality of engagement and its relation with satisfaction. J. Psychol. 2009, 143, 91-112. [CrossRef]

64. Carini, R.M.; Kuh, G.D.; Klein, S.P. Student engagement and student learning: Testing the linkages. Res. High. Educ. 2006, 47, 1-32. [CrossRef]

65. Fredricks, J.A.; McColskey, W. The measurement of student engagement: A comparative analysis of various methods and student self-report instruments. In Handbook of Research on Student Engagement; Christenson, S., Reschly, A., Wylie, C., Eds.; Springer: Boston, MA, USA, 2012; pp. 763-782. [CrossRef]

66. Hampden-Thompson, G.; Bennett, J. Science Teaching and Learning Activities and Students' Engagement in Science. Int. J. Sci. Educ. 2013, 35, 1325-1343. [CrossRef]

67. Li, Y.; Lerner, R.M. Interrelations of behavioral 2010, emotional, and cognitive school engagement in high school students. J. Youth Adolesc. 2013, 42, 20-32. [CrossRef] [PubMed]

68. Rotgans, J.I.; Schmidt, H.G. Situational interest and academic achievement in the active-learning classroom. Learn. Instr. 2011, 21, 58-67. [CrossRef]

69. Marton, F.; Säljö, R. On qualitative differences in learning: I-Outcome and process. Br. J. Educ. Psychol. 1976, 46, 4-11. [CrossRef]

70. Zhu, X.; Chen, A.; Ennis, C.; Sun, H.; Hopple, C.; Bonello, M.; Kim, S. Situational interest, cognitive engagement, and achievement in physical education. Contemp. Educ. Psychol. 2009, 34, 221-229. [CrossRef]

71. Ryan, F.; Coughlan, M.; Cronin, P. Step-by-step guide to critiquing research. Part 2: Qualitative research. Br. J. Nurs. 2007, 16, 738-745. [CrossRef]

72. Hakkarainen, P. Designing and implementing a PBL course on educational digital video production: Lessons learned from a design-based research. Educ. Technol. Res. Dev. 2009, 57, 211-228. [CrossRef]

73. Long, B.T.; Hall, T. R-NEST: Design-based research for technology-enhanced reflective practice in initial teacher education. Australas. J. Educ. Technol. 2015, 31. [CrossRef]

74. Wang, F.; Hannafin, M.J. Design-based research and technology-enhanced learning environments. Educ. Technol. Res. Dev. 2005, 53, 5-23. [CrossRef]

75. Collins, A.; Joseph, D.; Bielaczyc, K. Design research: Theoretical and methodological issues. J. Learn. Sci. 2004, 13, 15-42. [CrossRef]

76. Spencer, L.; Britain, G. Quality in Qualitative Evaluation: A Framework for Assessing Research Evidence; Government Chief Social Researcher's Office, The National Archives: Richmond, UK, 2003.

77. Renninger, K.A.; Bachrach, J.E. Studying triggers for interest and engagement using observational methods. Educ. Psychol. 2015, 50, 58-69. [CrossRef]

78. Liu, T.-C.; Peng, H.; Wu, W.-H.; Lin, M.-S. The Effects of Mobile Natural-science Learning Based on the 5E Learning Cycle: A Case Study. Educ. Technol. Soc. 2009, 12, 344-358. Available online: www.jstor.org/stable/jeductechsoci.12.4.344 (accessed on 3 June 2021). 
79. McHugh, M.; McCauley, V. Hooked on Science. Sci. Sch. Eur. J. Sci. Teach. 2017, 39, 55-58. Available online: https:/ /www.eso. org/public/archives/schools/pdf/sis_0039.pdf (accessed on 3 June 2021).

80. Köller, O.; Baumert, J.; Schnabel, K. Does Interest Matter? The Relationship between Academic Interest and Achievement in Mathematics. J. Res. Math. Educ. 2001, 32, 448-470. [CrossRef]

81. Wolfinger, N.H. On writing fieldnotes: Collection strategies and background expectancies. Qual. Res. 2002, 2, 85-93. [CrossRef]

82. Sanjek, R. Fieldnotes: The Makings of Anthropology; Cornell University Press: Ithaca, NY, USA, 1990.

83. Bodgan, R.C.; Biklen, S.K. Qualitative Research for Education: An Introduction to Theories and Methods, 4th ed.; Pearson Education Group: New York, NY, USA, 2003.

84. Lather, P. Issues of validity in openly ideological research: Between a rock and a soft place. Interchange 1986, 17, 63-84. [CrossRef]

85. Gall, M.D.; Gall, J.P.; Borg, W.R. Educational Research: An Introduction; Pearson/Allyn Bacon: Boston, MA, USA, 2007.

86. DiCicco-Bloom, B.; Crabtree, B.F. The qualitative research interview. Med Educ. 2006, 40, 314-321. [CrossRef]

87. Braun, V.; Clarke, V. Using thematic analysis in psychology. Qual. Res. Psychol. 2006, 3, 77-101. [CrossRef]

88. Fereday, J.; Muir-Cochrane, E. Demonstrating rigor using thematic analysis: A hybrid approach of inductive and deductive coding and theme development. Int. J. Qual. Methods 2008, 5, 80-92. [CrossRef]

89. Terry, G.; Hayfield, N.; Clarke, V.; Braun, V. Thematic Analysis. The Sage Handbook of Qualitative Research in Psychology; Sage Publications: Thousand Oaks, CA, USA, 2017; pp. 17-37.

90. Graneheim, U.H.; Lundman, B. Qualitative content analysis in nursing research: Concepts, procedures and measures to achieve trustworthiness. Nurse Educ. Today 2004, 24, 105-112. [CrossRef]

91. Saldaña, J. The Coding Manual for Qualitative Researchers; Sage Publications: Thousand Oaks, CA, USA, 2012.

92. Clarke, V.; Braun, V. Teaching thematic analysis: Overcoming challenges and developing strategies for effective learning. Psychologist 2013, 26, 120-123. Available online: https://uwe-repository.worktribe.com/output/937596/teaching-thematicanalysis-overcoming-challenges-and-developing-strategies-for-effective-learning (accessed on 3 June 2021).

93. Muldner, K.; Burleson, W.; VanLehn, K. “Yes!”: Using tutor and sensor data to predict moments of delight during instructional activities. In International Conference on User Modeling, Adaptation, and Personalization; Springer: Berlin/Heidelberg, Germany, 2010; pp. 159-170.

94. Arnone, M.P.; Small, R.V.; Chauncey, S.A.; McKenna, H.P. Curiosity, interest and engagement in technology-pervasive learning environments: A new research agenda. Educ. Technol. Res. Dev. 2011, 59, 181-198. [CrossRef]

95. Luce, M.R.; Hsi, S. Science-Relevant Curiosity Expression and Interest in Science: An Exploratory Study. Sci. Educ. 2015, 99, 70-97. [CrossRef]

96. Shenaar-Golan, V.; Gutman, C. Curiosity and the Cat: Teaching Strategies That Foster Curiosity. Soc. Work Groups 2013, 36, 349-359. [CrossRef]

97. Loewenstein, G. The psychology of curiosity: A review and reinterpretation. Psychol. Bull. 1994, 116, 75. [CrossRef]

98. Peters, C.; Castellano, G.; De Freitas, S. An exploration of user engagement in HCI. In Proceedings of the International Workshop on Affective-Aware Virtual Agents and Social Robots, Boston, MA, USA, 2-4 November 2009; pp. 1-3. [CrossRef]

99. Rotgans, J.I.; Schmidt, H.G. Situational interest and learning: Thirst for knowledge. Learn. Instr. 2014, 32, 37-50. [CrossRef]

100. Kashdan, T.B.; Silvia, P.J. Curiosity and interest: The benefits of thriving on novelty and challenge. Oxf. Handb. Posit. Psychol. 2009, 2, 367-374.

101. Chen, A.; Darst, P.W. Individual and situational interest: The role of gender and skill. Contemp. Educ. Psychol. 2002, 27, 250-269. [CrossRef]

102. Hidi, S.; Harackiewicz, J.M. Motivating the academically unmotivated: A critical issue for the 21st century. Rev. Educ. Res. 2000, 70, 151-179. [CrossRef]

103. Linvill, D. Student Interest and Engagement in the Classroom: Relationships with Student Personality and Developmental Variables. South. Commun. J. 2014, 79, 201-214. [CrossRef]

104. Subramaniam, P.R. Motivational effects of interest on student engagement and learning in physical education: A review. Int. J. Phys. Educ. 2009, 46, 11-19.

105. Flowerday, T.; Shell, D.F. Disentangling the effects of interest and choice on learning, engagement, and attitude. Learn. Individ. Differ. 2015. [CrossRef]

106. Ainley, M.; Hidi, S.; Berndorff, D. Interest, learning, and the psychological processes that mediate their relationship. J. Educ. Psychol. 2002, 94, 545-561. [CrossRef]

107. Hidi, S.; Renninger, K.A.; Krapp, A. Interest, a motivational variable that combines affective and cognitive functioning. In The Educational Psychology Series. Motivation, Emotion, and Cognition: Integrative Perspectives on Intellectual Functioning and Development; Dai, D.Y., Sternberg, R.J., Eds.; Lawrence Erlbaum Associates Publishers: Mahwah, NJ, USA, 2004; pp. 89-115.

108. Mazer, J.P. Associations among teacher communication behaviors, student interest, and engagement: A validity test. Commun. Educ. 2013, 62, 86-96. [CrossRef]

109. Palmer, D.H. Student interest generated during an inquiry skills lesson. J. Res. Sci. Teach. 2009, 46, 147-165. [CrossRef]

110. Silvia, P.J. Interest-The curious emotion. Curr. Dir. Psychol. Sci. 2008, 17, 57-60. [CrossRef]

111. Klassen 2011, S.; Klassen, C.F. The Role of Interest in Learning Science through Stories. Interchange 2014, 45, 133-151. [CrossRef]

112. Mayer, R.E.; Moreno, R. Nine ways to reduce cognitive load in multimedia learning. Educ. Psychol. 2003, 38, 43-52. [CrossRef]

113. Hidi, S. Interest: A unique motivational variable. Educ. Res. Rev. 2006, 1, 69-82. [CrossRef] 
114. Pace, B.G.; Jones, L.C. Teaching with web-based videos. Sci. Teach. 2009, 76, 47.

115. Jones, T.; Cuthrell, K. YouTube: Educational potentials and pitfalls. Comput. Sch. 2011, 28, 75-85. [CrossRef] 